\title{
ALIH KODE DALAM DIALOG NOVEL SURGA YANG TAK DIRINDUKAN KARYA ASMA NADIA
}

\author{
Rina Wulandari ${ }^{1}$; Sri Marmanto ${ }^{2}$; Sumarlam $^{3}$ \\ ${ }^{1}$ Magister Linguistik Pascasarjana Universitas Sebelas Maret, Surakarta, Indonesia \\ ${ }^{2}$ Universitas Sebelas Maret, Surakarta, Indonesia \\ ${ }^{3}$ Professor in Syntax at Universitas Sebelas Maret, Surakarta, Indonesia \\ ${ }^{1}$ rinawulandari009@gmail.com
}

\begin{abstract}
The objectives of this research are to explain: (1) the forms of code switching in a dialogue of novel Surga yang Tak Dirindukan, (2) the factors influencing of code switching in a dialogue of novel Surga yang Tak Dirindukan, (3) the functions of code switching in a dialogue of novel Surga yang Tak Dirindukan.

The research employed a Poplack's sociolinguistics approach. The research used qualitative descriptive method. The data were obtained from the dialogue of novel, then were analyzed by using the communicative ethnographic approach by considering the existing speech context, namely: speech components. The data of the research included speech dialogue in a novel containing code switching. The data collection of research began by determining of novel, documentation technique, classification technique, and coding of data technique. Then, used ethnographic method with domain analysis technique, taxonomic analysis technique, componential analysis technique, and cultural of themes analysis technique. The data were validated by using the triangulation technique and analyzed by means of the Spradley model of analysis.

The result of the research shows that the forms of code switching are tag switching, intra-sentential code switching, and inter-sentential code switching through the use of declarative, imperative, and interrogative sentences. Tag switching consists of 24 data, intra-sentential code switching consists of 12 data, and inter-sentential consists of 49 data. The factors influencing the code switching in a dialogue of novel include to quoting others' speech and being disposed for adjusting the language used with interlocutor. Finally, the functions of the code switching are to establish a good communication and to confirm the addressors' speech.

The conclusion of the research is that inter sentential code switching most often appears with a percentage $55.6 \%$, then tag switching is $29.6 \%$, and the last is intra sentential code switching $14.8 \%$. The factors influencing the code switching most often appears is Ends factor in inter sentential code switching with percentage $25.9 \%$ and rarely appears is act sequence factors in a tag switching with percentage $2.5 \%$. And the last the functions of code switching most often appears to convince the hearer functions in a inter sentential code switching with percentage $13.6 \%$.
\end{abstract}

Keywords: code switching, sociolinguistic study, Poplack's sociolinguistics approach, Surga yang Tak Dirindukan 


\section{PENDAHULUAN}

Peristiwa alih kode biasa terjadi dalam komunikasi lisan dan juga pada percakapan atau dialog (bahasa lisan yang dituliskan) antar tokoh dalam novel atau karya sastra lainnya. Alih kode (code switching) adalah salah satu gejala kebahasaan yang sering muncul dalam kehidupan sehari-hari. Gejala alih kode tersebut muncul ditengah-tengah tindak tutur secara disadari dan bersebab. Berbagai tujuan dari si pelaku tindak tutur yang melakukan alih kode dapat terlihat dari tuturan yang dituturkannya. Beberapa ahli telah memberikan batasan dan pendapat mengenai alih kode. Batasan dan pendapat tersebut diperoleh setelah mereka melakukan pengamatan terhadap objek yang melakukan alih kode dalam tindak tuturnya. Beberapa linguis memberikan definisi alih kode ini.

Menurut Poplack (1980), alih kode terdiri dari tiga jenis, yaitu Tag switching, Intra sentential switching, dan Inter sentential switching,

a. Alih Kode Penegas (Tag switching)

Menurut Poplack (1980), tag-switching adalah apabila alih kode berada diujung kalimat dan melibatkan penyisipan ekor kalimat (tag).

Contoh (Wardaugh, 1992):

The proceeding went smoothly, ba? (Tagalog)

(Prosesnya berjalan lancar, ya kan?).

\section{b. Intra-sentential switching}

Menurut Poplack (1980), alih kode intra-sentential adalah peralihan dari bahasa satu ke bahasa yang lain yang terjadi didalam sebuah kalimat yang melibatkan satuan sintaksis kata, frasa atau klausa. Hal serupa diungkapkan oleh Appel \& Muysken (1987:118), “Intra-sentential switching occurs within a sentence." Alih kode intra- 
sentential adalah peralihan dari satu bahasa kebahasa lain yang terjadi didalam suatu kalimat. Satuan sintaksis yang terlibat dalam alih kode ini adalah kata, frasa, dan klausa.

Alih kode sering dilakukan oleh masyarakat Indonesia dalam bentuk lisan maupun tulisan, khususnya yang terdapat dalam buku bacaan karya sastra seperti novel. Novel adalah karangan prosa yang panjang mengandung rangkaian cerita kehidupan seseorang dengan orang sekelilingnya dengan menonjolkan watak dan sifat setiap pelaku (KBBI 2003:788). Pemilihan novel Surga Yang Tak Dirindukan sebagai objek penelitian berdasarkan beberapa alasan. Pertama, Novel Surga Yang Tak Dirindukan dikarang oleh salah satu sastrawan terkenal sekaligus sebagai dai yang telah menghasilkan novel-novel yang digemari pembaca, novel Surga Yang Tak Dirindukan juga sarat dengan perjuangan hidup, cinta, serta nila-nilai moral dan agama yang berguna bagi pembaca terutama generasi muda. Kedua, Novel Surga Yang Tak Dirindukan berdasarkan temuan peneliti, penulis sering memunculkan beberapa peristiwa kebahasaan yaitu bahasa daerah (Jawa), bahasa asing (Cina, Sinhala dan Inggris) yang berupa alih kode berbentuk dialog antar tokoh.

\section{TEORI DAN METODE PENELITIAN}

\section{Teori}

Menurut Apple (1976:79), alih kode adalah gejala peralihan dalam pemakaian bahasa karena berubahnya situasi. Hymes (1875:103) berpendapat bahwa alih kode tidak hanya terjadi antar bahasa, tetapi dapat juga terjadi antar ragam-ragam atau gayagaya yang terdapat dalam satu bahasa. Namun karena di dalam suatu kode terdapat berbagai kemungkinan variasi (baik variasi rasional, variasi kelas sosial, ragam, gaya atau register) maka peristiwa alih kode mungkin berwujud alih varian, alih ragam, alih 
gaya atau alih register. Peralihan juga dapat diamati melalui tingkat-tingkat tata bunyi, tata kata, tata bentuk, tata kalimat, maupun tata wacananya.

Menurut Poplack (2004) bahwa "code switching refers to the utterance-internal uxtaposition, in unintergrated form, of overt linguistic elements from two or more language, with no necessary change of interlocutor or topic". "Alih kode merujuk kedalam tuturan, dalam bentuk tidak diintergrasikan, dengan unsure bahasa dari dua bahasa atau lebih, dengan tidak ada pergantian dari mitra tutur atau topik'. Selanjutnya, Marmanto dalam perkuliahan yang dikutip dari Poplack (1980) mendeskripsikan bahwa "alih kode terdiri dari tag switching, intra-sentensial, dan intersentensial". Uraian tadi menunjukkan adanya perbedaan teori alih kode dengan teori alih kode pada umumnya. Dikatakan demikian, karena alih kode dalam hal ini berupa beralihnya bahasa penutur dari tataran satuan lingual penegas, kata, frasa, klausa, dan kalimat, sedangkan teoriteori yang diungkapkan oleh Fasold (dalam Chaer dan Agustina 2010:115) Suwito (dalam Mulyani, 2004:48-49) bahwa penutur dikatakan beralih kode, jika penutur menyisipkan satuan lingual kalimat bahasa lain kebahasa yang dituturkan sebelumnya, sedangkan bila penutur menyisipkan satuan lingual kata, frasa, kata majemuk, idiom, dan klausa, maka penutur tersebut bercampur kode.Penelitian ini merupakan penelitian kualitatif dengan mengambil data dari dialog novel yang berjudul Surga Yang Tak Dirindukan, yang notabene memiliki banyak ragam bahasa di dalamnya. Ada lima bahasa yang digunakan dalam dialog novel Surga Yang Tak Dirindukan ini, yaitu bahasa Indonesia, bahasa Jawa, bahasa Inggris, bahasa Cina, dan bahasa Sinhala. Banyaknya ragam bahasa yang digunakan dalam dialog novel Surga Yang Tak Dirindukan memungkinkan peneliti untuk meneliti novel ini karena peristiwa alih kode 
yang terjadi pun sangat memungkinkan untuk diteliti. Penelitian ini menghasilkan data deskriptif berupa data tertulis.

\section{Lokasi Penelitian}

Penelitian ini menggunakan sumber data berupa novel, maka penelitian dapat dilakukan dimanapun peneliti berada. Hal ini sangat memudahkan peneliti karena tidak terpaku dengan satu tempat penelitian saja, tetapi bisa berpindah-pindah tempat ketika sudah tidak merasa nyaman dengan tempat penelitian yang sebelumnya. Adapun tempat-tempat yang didatangi peneliti untuk melakukan penelitian seperti diruang belajar, kampus, dan perpustakaan Universitas Sebelas Maret.

\section{Subjek dan Objek Penelitian}

Subjek penelitian dalam analisis alih kode ini adalah tokoh-tokoh yang terdapat dalam novel Surga Yang Tak Dirindukan. Subjek penelitian ini ditentukan setelah peneliti melakukan prasurvey dengan membaca beberapa novel yang terkait alih kode didalamnya. Kemudian, objek didalam penelitian ini adalah tuturan yang terdapat pada novel Surga Yang Tak Dirindukan yang didalamnya terdapat peristiwa alih kode.

\section{Data dan Sumber Data}

Data dan sumber data merupakan bagian yang paling utama didalam penelitian. Betapa tidak, karena tanpa adanya data dan sumber data, maka penelitian akan tidak bisa dilakukan. Kesalahan memilih sumber data akan sangat berdampak pada tingkat validitas data dalam penelitian. Sutopo (2006:58-59) menjelaskan bahwa "peristiwa sebagai sumber data memang sangat beragam, dari berbagai peristiwa, baik yang terjadi secara sengaja ataupun tidak". Bertitik tolak dari teori tadi, maka data dalam penelitian ini tuturan yang didalamnya terdapat alih kode baik dalam bentuk kata, frasa, klausa, 
ataupun kalimat. Sementara itu sumber data pada penelitian ini yaitu novel Surga Yang Tak Dirindukan karya Asma Nadia.

\section{Teknik Pengumpulan Data}

Teknik pengumpulan data menggunakan beberapa teknik diantaranya:

1) teknik penentuan novel, yaitu memilah-milah dan membaca-baca novel yang sekiranya banyak mengandung alih kode, ternyata dalam dialog novel Surga Yang Tak Dirindukan banyak mengandung alih kode baik berupa kata, frasa, maupun kalimat.

2) teknik dokumentasi, yaitu mencatat dan mengumpulkan data-data temuan berupa alih kode bahasa yang terdapat dialog dalam novel Surga Yang Tak Dirindukan karya Asma Nadia.

3) teknik pengklasifikasian atau pemisahan, yaitu memisahkan alih kode yang terdapat dalam dialog novel Surga Yang Tak Dirindukan karya Asma Nadia dengan cara menandai kasus-kasus yang ada, baik itu dalam dialog maupun dalam kalimatkaliamat uraian.

4) teknik pengkodean data, yaitu memberi kode terhadap segmen-segmen data yang terdapat dalam dialog novel Surga Yang Tak Dirindukan karya Asma Nadia. Dalam melakukan pengodean, peneliti menandai data dengan nomor data dan kode data yang terdapat dalam tuturan novel Surga Yang Tak Dirindukan. Hal ini dilakukan untuk membedakan data-data yang terdapat dalam tuturan tersebut.

\section{Instrumen Penelitian}

Instrumen penelitian yang digunakan adalah human instrument, yaitu peneliti sendiri yang berperan sebagai perencana, pelaksana, pengumpul data, penganalisis, pengolah data, sampai pada tahap pelaporan hasil penelitian. Dalam hal ini didukung 
dengan seperangkat teori tentang jenis, bentuk, faktor penyebab, dan fungsi alih kode, termasuk parameter alih kode.

\section{Validitas Data}

Keabsahan data pada penelitian alih kode ini dugunakan untuk pengukuran akurasi yakni keakuratan antara hasil penelitian dengan analisis yang dibangun. Dengan harapan bahwa penelitian ini akan tercapai adanya absahan data dan dapat dijadikan sebagai masukan dalam daftar hasil penelitian bahasa. Dalam penelitian ini, pengecekan data dilakukan dengan cara-cara sebagai berikut.

a. Melakukan penelitian atau pencarian data dengan cara yang continue sesuai fakta yang ada dalam data yang sebenar-benarnya.

b. Melakukan pengamatan dan pencatatan dengan tekun dan teliti untuk mendapatkan data yang benar-benar akurat.

a. Triangulasi

Triangulasi dilakukan dengan dua cara, yaitu sebagai berikut:

- Penggunaan beberapa sumber data, yaitu melakukan pengecekan dengan kamus. Kamus yang digunakan adalah kamus bahasa Indonesia, bahasa Jawa, bahasa Inggris, bahasa Arab dan bahasa Cina.

- Melalui peneliti, yaitu peneliti juga melakukan konsultasi dengan para pakar yang menguasai bahasa Jawa, bahasa Inggris, bahasa Cina, bahasa Arab dan juga pakar sosiolinguistik.

\section{Teknik Analisis Data}

Teknik analisis data merujuk kepada teknik-teknik yang dilakukan dengan jalan bekerja dengan data (Bogdan \& Biklen, dalam Moleong, 2012: 248), mengorganisasikan data, memilah-milah menjadi satuan yang dapat dikelola, 
mengintensitaskan, mencari dan mempelajari, dan memutuskan yang dapat diceritakan kepada orang lain. Sedangkan menurut Spradley (2006: 129) merujuk kepada pada pengujian sistematis terhadap sesuatu untuk menentukan bagian-bagiannya, hubungan diantara bagian-bagian tersebut, serta hubungan-hubungan tersebut secara keseluruhan.

Data yang diperoleh tersebut akan dianalisis dengan menggunakan komponen tutur yang diakronimkan dengan SPEAKING yang diungkapkan oleh Hymes (dalam Sumarsono 2012: 335) yakni, S (Setting and Scenes), P (Participants), E (Ends), A (Act Squences), K (Key), I (Instrumentialities), N (Norms), G (Genres).

Penelitian ini menggunakan model analisis data yang diusulkan oleh Spradley karena penelitian ini merupakan menggunakan data-data etnografis. Analisis data dimulai dengan menemukan domain penelitian terlebih dahulu. Menurut Grbich (dalam Santosa, 2014: 67), domain penelitian merujuk kepada pengertian bagian organik alamiah dari struktur besar fenomena budaya.

Kemudian, analisis data dilanjutkan dengan analisis taksonomi. Taksonomi merujuk kepada kelompok-kelompok atau kategori-kategori alamiah realitas obyek penelitian yang berhasil direduksi dari domain (Santosa, 2014: 75). Analisis taksonomi mengelompokan data-data yang diperoleh kedalam kategori yang berhasil didapat dari domain atau berdasarkan teori-teori dan pendekatan yang digunakan.

Analisis komponensial bertujuan untuk menghubungkan komponen atau aspek yang telah dilakukan pada analisis domain taksonomi. Selanjutnya, analisis data berusaha untuk menemukan tema-tema budaya yang tersirat maupun yang tersurat dalam data yang telah dianalisis pada tahap analisis komponensial. Spradley (2006:267) mendefinisikan tema budaya sebagai prinsip-prinsip kognitif yang bersifat tersirat 
maupun tersurat yang berlangsung dalam sejumlah sistem domain dan berperan sebagai suatu sistem hubungan diantara berbagai subsistem dan makna budaya.

\section{TEMUAN DAN PEMBAHASAN}

\section{Temuan}

\section{Wujud Alih Kode}

Wujud peralihan kode yang ditemukan dalam dialog novel Surga Yang Tak Dirindukan Karya Asma Nadia terdiri dari alih kode penegas, alih kode intra sentensial, dan alih kode inter sentensial. Terkait dengan hal tersebut, alih kode dalam dialog novel Surga Yang Tak Dirindukan karya Asma Nadia ini melibatkan Lima bahasa yakni, bahasa Jawa, bahasa Inggris, bahasa Cina, bahasa Arab, dan bahasa Sinhala. Adapun bentuk alih kode dalam novel tersebut; 1) alih kode penegas yang berupa alih kode dari bahasa Indonesia ke bahasa Inggris dan sebaliknya, alih kode dari bahasa Indonesia ke bahasa Jawa dan sebaliknya, alih kode dari bahasa Indonesia ke bahasa Arab. 2) alih kode intra sentensial yang terdiri dari alih kode dari bahasa Indonesia ke bahasa Inggris dan sebaliknya, alih kode dari bahasa Indonesia ke bahasa Jawa dan sebaliknya, alih kode dari bahasa Indonesia ke bahasa Cina dan sebaliknya; 3) alih kode inter sentensial yang terdiri dari alih kode bahasa Indonesia ke bahasa Inggris dan sebaliknya, alih kode dari bahasa bahasa Indonesia ke bahasa Jawa dan sebaliknya, alih kode dari bahasa Cina ke bahasa Indonesia dan sebaliknya, dan yang terakhir adalah alih kode dari bahasa Indonesia ke bahasa Sinhala. Dari beberapa alih kode yang terurai diatas, tokoh dalam novel Surga Yang Tak Dirindukan dominan menggunakan wujud peralihan kode inter sentensial dari bahasa Indonesia ke bahasa Inggris.

a. Alih kode penegas

$$
\text { Arini } \quad \text { Wah, Mas Pras romantis }
$$


Prasetya : Itu lagu kesukaan Mas

Arini : Nadanya gimana, Mas?

Data diatas adalah bentuk peralihan kode penegas yang terjadi antara Prasetya dan Istrinya yang sedang berlangsung di salah satu kamar di rumah milik mereka. Waktu berlangsungnya penuturan adalah sore hari dengan situasi tuturan santai karena tuturan tersebut terjadi antara Prasetya dan Arini yang memiliki hubungan kekerabatan sebagai suami dan istri yang telah memiliki 3 orang anak. Prasetya berusia sekitar 35 tahun dan Arini 30 tahun. Pada peristiwa itu Prasetya sedang menyanyikan sebuah lagu untuk Arini, hal ini dibuktikan dengan tuturan kalimat "Itu lagu kesukaan Mas". Tujuan dari percakapan tersebut yaitu Prasetya ingin membuat istrinya merasa bahagia dengan lagu yang telah dinyanyikannya. Dalam peristiwa tutur diatas menggunakan satuan lingual bentuk penegas Wah yang bermakna sebagai seruan dan berupa pujian dari Arini untuk Prasetya. Alih kode yang terjadi diatas adalah alih kode penegas, yaitu munculnya satuan lingual bahasa Jawa berupa kata seruan yang dilakukan oleh Arini. Alih kode ini dilakukan dengan maksud untuk suasana yang akrab dan lebih romantis diantara penutur. Dalam alih kode tersebut menggunakan jenis kalimat intrerogatif dan deklaratif yaitu kalimat yang berisi sebuah pertanyaan. Selanjutnya nada yang digunakan dalam peristiwa tutur diatas berupa nada sedang. Norma yang digunakan dalam beralih kode dalam peristiwa tuturan dialog diatas yaitu norma kesopanan. Sementara itu dimensi sosial yang dapat kita temukan dalam tuturan diatas adalah skala jarak sosial dan skala formalitas. Skala formalitas ini berkaitan dengan tingkat formalitas atau jenis interaksi yang digunakan oleh para penutur, yaitu informal.

b. Alih kode intra sentensial

Ibu Arini $\quad$ : Ternyata perkiraan salah, Rin. Ujian terbesar muncul di tahun keenam pernikahan, ketika perempuan itu menemukan suaminya diam-diam sudah menikah dengan teman sekolahnya dulu. Cinta pertama yang tak pernah mendapat kesempatan 
Berbulan-bulan lelaki itu tak pernah pulang. Lali karo istri, lali karo anak-anake. Padahal dia sebelumnya adalah bapak yang baik..

Arini : Seharusnya perempuan itu pergi!

Ibu Arini : : Nyaris saja Nduk.. jika dia tidak melihat sesuatu.

Kutipan dialog yang ditunjukkan oleh data no 6 di atas adalah peristiwa tutur antara Arini dan Ibunya yang sedang berlangsung di salah satu ruang keluarga di kediaman orang tua Arini. Waktu berlangsungnya penuturan adalah pada sore hari dengan situasi tuturan santai karena tuturan tersebut terjadi antara Arini dan Ibunya yang memiliki hubungan kekerabatan sebagai orang tua dan anak. Pada peristiwa itu Ibu Arini menceritakan kisah hidup yang pernah dialami dalam rumah tangganya, hal ini dibuktikan dengan tuturan kalimat "Ternyata perkiraan salah, Rin. Ujian terbesar muncul di tahun keenam pernikahan, ketika perempuan itu menemukan suaminya diamdiam sudah menikah dengan teman sekolahnya dulu. Cinta pertama yang tak pernah mendapat kesempatan”. Setetes air mata meluncur, namun dengan cepat sehelai sapu tangan menyerapnya sampai tandas di pipi wanita yang berusia setengah baya itu. Tujuan dari percakapan tersebut yaitu Ibu Arini ingin berbagi pengalaman kepada anaknya mengenai masalah hidup yang pernah terjadi antara kedua orang tuanya. Dalam peristiwa tutur diatas menggunakan satuan lingual bentuk intra sentensial berupa kata, diawali dengan bahasa Indonesia dan mendapat imbuhan dari bahasa Jawa yaitu anakanake yang digunakan oleh penutur bahasa Indonesia, dan artinya adalah "anakanaknya”. Alih kode yang terjadi diatas adalah alih kode intra sentensial, yaitu munculnya satuan lingual bentuk kata dari bahasa Indonesia yaitu anak-anak dengan mendapat imbuhan dari bahasa Jawa yaitu $\boldsymbol{e}$, apabila disatukan menjadi kata anakanake dan memiliki arti "anak-anaknya" yang disisipkan dalam tuturan oleh penutur bahasa Indonesia dan digunakana untuk menceritakan pengalaman hidup yang pernah 
dilalui oleh ibu Arini. Alih kode ini dilakukan dengan situasi yang sedang hening dan sedih. Dalam alih kode tersebut menggunakan jenis kalimat deklaratif yaitu kalimat yang berisi sebuah informasi mengenai pengalaman hidup yang pernah dilalui oleh Ibu Arini. Selanjutnya yaitu nada yang digunakan dalam tuturan pada peristiwa tutur diatas adalah nada sedang. Kemudian norma yang digunakan dalam beralih kode pada peristiwa tutur diatas yaitu norma kesopanan. Sementara itu dimensi sosial yang dapat kita temukan dalam tuturan diatas adalah skala jarak sosial dan skala formalitas.

c. Alih kode inter sentensial
Lulu
: Siapa yang mau married?
Sita
: Semua juga mau. Memangnya kamu nggak?
Lulu : Gimana bisa nikah kalau kalian ngga pacaran?
Arini
: Jadi akhirnya,
Pangeran dan putri akan hidup happily ever after... mm..
Setidaknya sampai kematian memisahkan mereka.

Temuan data no 4 yang terdapat dalam dialog di atas adalah peristiwa tutur yang terjadi antara Lulu, Sita, dan Arini yang sedang berlangsung di sebuah rumah kontrakan yang mereka tempati ketika mereka sedang menempuh pendidikan di bangku perguruan tinggi di Bogor. Waktu berlangsungnya penuturan adalah pada sore hari dengan situasi tuturan santai karena tuturan tersebut terjadi antara Lulu, Sita, dan Arini yang memiliki hubungan kekerabatan sebagai teman. Usia Lulu, Sita, Arini dalam peristiwa tutur diatas adalah sekitar 20 tahun karena ketika terjadinya tuturan tersebut status mereka adalah sebagai seorang mahasiswa. Tujuan dari percakapan tersebut yaitu ingin mendapatkan sebuah informasi mengenai sebuah kabar yang di dengar oleh Lulu mengenai sahabatnya yang akan menikah. Dalam peristiwa tutur diatas menggunakan satuan lingual bentuk intrer sentensial berupa frasa happily ever after yang dituturkan oleh penutur bahasa Indonesia, artinya adalah "bahagia selamanya". Alih kode yang terjadi diatas adalah alih kode intrer sentensial, yaitu munculnya satuan lingual berupa frasa 
dari bahasa Inggris ke dalam bahasa Indonesia yang digunakana untuk memberikan gambaran suatu peristiwa yang akan terjadi. Bentuk dari peralihan kode intra sentensial diatas yaitu berupa frasa eksosentris. Dalam tuturan pada peristiwa peralihan kode tersebut menggunakan jenis kalimat interogatif karena sudah terlihat jelas bahwa kalimat tersebut merupakan sebuah pertanyaan yang membutuhkan jawaban. Kemudian nada yang digunakan dalam peristiwa tutur diatas berupa nada sedang. Kemudian norma, norma yang digunakan dalam beralih kode pada peristiwa tuturan dialog diatas yaitu norma kesopanan. Selanjuutnya dimensi sosial yang dapat kita temukan dalam tuturan diatas adalah dua skala fungsional dan skala formalitas. Dua skala fungsional yang dimaksud disini adalah sebuah tuturan yang berisi tentang gosip atau suatu berita yang belum jelas kebenarannya. Kemudian ditemukan juga skala formalitas, skala formalitas ini berkaitan dengan tingkat formalitas atau jenis interaksi yang digunakan oleh para penutur, yaitu informal.

\section{Faktor Penyebab Terjadinya Alih Kode}

Bagi penutur yang menguasai lebih dari satu bahasa, ia akan mengganti kode bahasanya sesuai dengan bahasa yang digunakan lawan tuturnya. Faktor-faktor yang mempengaruhi penggantian kode bahasa itu meliputi:penutur, mitra tutur (participant), hadirnya penutur ketiga, pokok pembicaraan (topik), situasi tutur, tujuan dalam bertutur, dan lain-lain. Namun dalam penelitian ini peneliti hanya menemukan beberapa faktor saja, yaitu mitra tutur, topik pembicaraan, situasi tutur dan tujuan.

Pada data dibawah ini menunjukkan peristiwa peralihan kode inter sentensial yang terjadi di sebuah kamar kontrakan. Peristiwa tutur terjadi antara Lulu dengan Sita dalam suasana pembicaraan yang santai. Topik pembicaraan yang melatarbelakangi 
peristiwa alih kode tersebut adalah pembicaraan mengenai kabar burung sebuah pernikahan.
Lulu
: "Siapa yang mau married?"
Sita
: "Semua juga mau. Memangnya kamu nggak?"
Lulu
: "Gimana bisa nikah kalau kalian nggak pacaran?"

Pada data diatas, awalnya penutur pertama menggunakan bahasa Indonesia yang kemudian beralih kode menggunakan bahasa Inggris. Lulu menggunakan bahasa Indonesia kemudian beralih kode menggunakan bahasa Inggris saat bertanya kepada sita mengenai kebenaran sebuah pernikahan. Peralihan kode ini dilakukan dengan tujuan untuk menekankan topik pembicaraan. Penggunaan bahasa Inggris ini ditunjukkan dengan adanya kata Married dalam kalimat "Siapa yang mau married?"

\section{Fungsi Alih Kode}

Pada peristiwa tutur yang terjadi dalam novel Surga Yang Tak Dirindukan ini terdapat beberapa fungsi yang melatarbelakangi adanya alih kode, diantaranya: 1) untuk menerangkan atau menjelaskan, 2) untuk menghormati mitra tutur, 3) untuk mengakrabkan diri, 4) untuk mengubah situasi atau humor, 5) untuk mengutip ucapan orang lain, 6) untuk sekedar bergengsi, 7) untuk menunjukkan rasa marah, dan 8) untuk meyakinkan mitra tutur.

Data dibawah ini menunjukkan peristiwa alih kode inter sentensial yang terjadi di sebuah apartemen. Peristiwa tutur terjadi antara Bobby dengan Temannya, dalam suasana yang santai. Topik pembicaraan yang melatarbelakangi peristiwa alih kode tersebut adalah pembicaraan mengenai munculnya pesan singkat berupa email yang menarik perhatian.

$$
\begin{array}{ll}
\text { Bobby } & \text { : "Hei, } \text { check this out!" } \\
\text { Teman Bobby } & \text { : "Coba cek e-mail gue," }
\end{array}
$$


"Hei, gue juga dapat, nih!"

Bobby : : "Kayak apa ya orangnya?"

"Seksi nggak, ya?"

Pada data diatas, awalnya penutur pertama menggunakan bahasa Indonesia, yang kemudian beralih kode menggunakan bahasa Inggris. Pada awalnya Bobby menggunakan bahasa Indonesia saat memberitahukan ada email masuk kepada temannya, kemudian beralih kode menggunakan bahasa Inggris. Terjadinya alih kode ini ditandai dengan munculnya peralihan bahasa Indonesia ke dalam bahasa Inggris yang dilakukan oleh Bobby. Penggunaan bahasa pertama adalah bahasa Indonesia, kemudian beralih kode menggunakan bahasa Inggris karena penutur pertama bermaksud ingin menunjukkan kemampuan berbahasa asing si penutur kepada lawan tutur. Penggunaan bahasa Inggris ini ditandai dengan kata Hei, Check this out!

\section{Pembahasan}

\section{Wujud Alih Kode}

Ihwal penelitian alih kode juga dilakukan oleh Rosnita dengan judul Analisis Alih Kode dan Campur Kode Pada Novel Kuantar Ke Gerbang Karya Ramadhan K. H. pada tahun 2013 menerangkan bahwa alih kode pada novel tersebut menggunakan dua bahasa, yaitu (1) alih kode intern, dari bahasa Indonesia ke bahasa Sunda dan (2) alih kode ekstern, dari bahasa Indonesia ke bahasa Belanda. Kemudian Campur kode pada novel tersebut menggunakan empat bahasa, yaitu (1) campur kode ke dalam, antara bahasa Indonesia dengan bahasa Sunda, antara bahasa Indonesia dengan bahasa Jawa; (2) campur kode keluar, antara bahasa Indonesia dengan bahasa Belanda, antara bahasa Indonesia dengan bahasa Inggris; dan (3) campur kode campuran, antara bahasa Indonesia dengan bahasa Belanda dan bahasa Jawa, antara bahasa Indonesia dengan 
bahasa Inggris dan bahasa Jawa. Penyebab terjadinya campur kode ada novel tersebut adalah identifikasi peranan (register, sosial, dan eduaksional), identifikasi ragam, dan keinginan untuk menjelaskan dan menafsirkan.

Berbeda dengan penelitian yang dilakukan oleh Rosnita, pada penelitian novel Surga Yang Tak Dirindukan ini peneliti lebih menfokuskan pada wujud alih kode yang terdapat di dalam kalimat pada tuturan yang dilakukan oleh penutur dalam novel tersebut yaitu, wujud alih kode penegas, intra sentensial, dan inter sentensial, sedangkan penelitian yang dilakukan oleh Rosnita lebih menujukkan jenis peralihan kode intern dari bahasa Sunda dan peralihan kode ekstern dari bahasa Belanda saja. Selain adanya perbedaan pada penelitian yang dilakukan oleh Rosnita dengan judul Analisis Alih Kode dan Campur Kode Pada Novel Kuantar Ke Gerbang Karya Ramadhan K. H. diatas juga terdapat adanya persamaan, yaitu persamaan pada tataran jenis alih kode yang diteliti, diantaranya pada tataran bentuk kata, frasa, klausa, dan juga kalimat.

\section{Faktor yang Mempengaruhi Terjadinya Alih Kode}

Penelitian yang terkait dengan alih kode pada novel juga terdapat pada penelitian Tesis yang dilakukan oleh Djirong dengan judul Alih Kode dan Campur Kode dalam Novel Karya Pandir Kelana pada tahun 2011. Isi dari penelitian yang diperoleh yaitu variasi bentuk alih kode dan campur kode berupa (1) bahasa Indonesia (BI) ke bahasa Jawa (BJ), (2) bahasa Indonesia (BI) ke bahasa Belanda (BB), (3) bahasa Indonesia (BI) ke bahasa Inggris (BIng), dan (4) bahasa Indonesia (BI) ke bahasa Jepang (BJp). Selain itu, ditemukan juga faktor-faktor pembangkit alih kode dan campur kode, yaitu (1) berubahnya lawan bicara, (2) pengaruh maksud-maksud tertentu si pembicara, (3) pengaruh keinginan menyesuaikan kode bahasa yang dikuasai oleh 
lawan bicara, (4) pengaruh materi percakapan, (5) pengaruh situasi bicara dan ujaran tetap seperti frasa, basa-basi, dan pepatah.

Hasil penelitian peralihan kode yang dilakukan oleh Djirong di atas, terdapat beberapa kesamaan dengan fenomena peralihan kode yang terdapat dalam novel Surga Yang Tak Dirindukan. Dikatakan demikian, karena peralihan kode yang dilakukan oleh tokoh dalam novel Surga Yang Tak Dirindukan bertujuan untuk memperlancar proses komunikasi antar tokoh, begitu juga dengan hasil penelitian yang dilakukan oleh Djirong. Selain itu terdapat juga perbedaan dengan penelitian yang telah dilakukan oleh Djirong, yaitu dalam penelitian yang dilakukan Djirong terdapat hubungan antara alih kode dengan campur kode, sementara pada penelitian dalam novel Surga Yang Tak Dirindukan ini lebih menitikberatkan pada analisis peralihan kode saja. Kemudian penelitian yang dilakukan oleh Djirong tersebut merupakan analisis dari semua teks yang terdapat dalam novel, yaitu bentuk dialog maupun monolog sedangkan dalam penelitian alih kode dalam novel Surga Yang Tak Dirindukan ini lebih spesifik dalam bentuk dialognya saja.

\section{Fungsi Alih Kode}

Penelitian peralihan kode juga pernah dilakukan oleh Siti Rohmani, Amir Fuady, dan Atikah Anindyarini dengan judul Analisis Alih Kode dan Campur Kode Pada Novel Negeri 5 Menara Karya Ahmad Fuadi. Hasil penelitiannya adalah sebagai berikut. Pertama, gejala alih kode terjalin dalam empat formasi. Gejala campur kode terjalin dalam tujuh formasi. Kedua, faktor pendorong alih kode berkaitan dengan pembicara dan pribadi pembicara, mitra tutur, fungsi dan tujuan pembicaraan, dan situasi pembicaraan Faktor pendukung meliputi alih kode extralinguistik dan intralinguistik. Faktor extralinguistik berkaitan dengan 
karakteristik speaker seperti latar belakang sosial, religiusitas perasaan, tingkat pendidikan, dan lokalitas perasaan. Faktor Intralinguistik berkaitan dengan adanya kata-kata dalam bahasa yang dapat menampung konsep makna yang dimaksudkan dalam elemen linguistik dimasukkan. Ketiga, fungsi alih kode dan campur kode novel Negeri 5 Menara karya Ahmad Fuadi adalah untuk menjelaskan, memerintah, berdoa, bertanya, dan menegaskan maksud.

Perbedaan hasil penelitian alih kode dalam novel Surga Yang Tak Dirindukan dengan penelitian diatas yaitu pada penelitian Rohmani, Fuady, dan Anandyarini fungsi yang terdapat dalam alih kode tersebut dipengaruhi oleh faktor-faktor extralinguistik dan intralinguistik, sementara pada penelitian alih kode dalam novel Surga Yang Tak Dirindukan ini hanya difokuskan pada konteks tuturan yang dilakukan oleh para tokoh didalam novel itu saja.

\section{Simpulan}

Berdasarkan hasil analisis dan pembahasan alih kode dalam dialog novel Surga Yang Tak Dirindukan karya Asma Nadia dapat peneliti simpulkan sebagai berikut. Pertama, wujud alih kode dalam dialog novel Surga Yang Tak Dirindukan yang ditemukan adalah sebanyak 81 data yang terdiri dari alih kode penegas 24 data, alih kode intra sentensial 12 data, dan alih kode inter sentensial 45 data. Dalam peralihan kode penegas terdapat alih kode berupa kata sebanyak 24 data. Kemudian dalam peralihan kode intra sentensial terdapat alih kode berupa kata sebanyak 6 data, frasa 4 data, dan klausa 2 data. Dan yang terakhir peralihan kode inter sentensial terdapat peralihan kode berupa kata sebanyak 12 data, frasa 8 data, klausa 6 data, dan kalimat sebanyak 19 data. Dari jumlah tersebut wujud alih kode yang dominan muncul adalah 
bentuk peralihan kode inter sentensial yaitu 55,6\% kemudian yang kedua yaitu peralihan kode penegas dengan persentase sebanyak 29,6\%, dan yang terakhir yaitu wujud peralihan kode penegas dengan jumlah persentase $14,8 \%$.

Kedua, faktor yang melatarbelakangi penyebab terjadinya alih kode dalam dialog novel Surga Yang Tak Dirindukan ada empat, yaitu (1) penutur, (2) topik pembicaraan, (3) situasi tutur, dan (4) tujuan. Dari keempat faktor tersebut yang paling sering muncul ialah faktor tujuan dalam wujud peralihan kode inter sentensial dengan jumlah persentase sebanyak $25,9 \%$. Kemudian, faktor yang paling jarang muncul yaitu topik pembicaraan pada wujud peralihan kode penegas yaitu sebanyak 2 data atau 2,5\%. Dan juga faktor topik pembicaraan dan situasi tutur pada wujud peralihan kode intra sentensial dengan jumlah data sebanyak 2 atau persentase sebanyak 2,5\%

Ketiga, fungsi yang melatarbelakangi terjadinya alih kode dalam dialog novel Surga Yang Tak Dirindukan ada sembilan, yaitu (1) untuk menerangkan atau menjelaskan, (2) untuk menghormati lawan tutur, (3) untuk mengakrabkan diri, (4) untuk mengubah situasi atau humor, (5) untuk mengutip ucapan orang lain, (6) untuk sekedar bergengsi, (7) untuk menunjukkan rasa marah, dan (8) meyakinkan mitra tutur, dan yang terakhir (9) menunjukkan kemampuan berbahasa. Dalam analisis yang peneliti lakukan ini, peneliti dapat mengambil kesimpulan bahwa meyakinkan mitra tutur dalam peralihan kode inter sentensial memiliki jumlah persentase yang paling banyak muncul, atau dominan dengan jumlah data sebanyak 11 data dan persentase sejumlah 13,6\%.

\section{Saran}

Adapun saran yang akan peneliti sampaikan dalam penelitian ini berkaitan dengan peristiwa tutur yang terjadi pada novel Surga Yang Tak Dirindukan, yaitu: 
1. Hasil penelitian mengenai alih kode dalam dialog novel Surga Yang Tak Dirindukan ini dapat menjadi acuan bagi para pembaca, khususnya yang ingin melakukan penelitian lebih mendalam tentang alih kode dalam sebuah karya sastra berupa novel pada umumnya.

2. Peristiwa alih kode juga dapat dijumpai dalam kehidupan sehari-hari pada proses komunikasi diberbagai tempat dan kalangan, tidak hanya dalam karya sastra berupa novel saja. Hal tersebut menunjukkan bahwa penelitian tentang alih kode dapat dilakukan pada proses komunikasi langsung yang terjadi antara penutur dan mitra tuturnya dalam ranah keluarga, pendidikan, ataupun sosial.

\section{Daftar Pustaka}

Apple, Rene, Muysken. 1987. Language Contect and Bilingualism. London: Edward.

Djirong, Salmah. 2011. Alih Kode dan Campur Kode dalam Novel Karya Pandir Kelana. Tesis pada Program Studi Bahasa Indonesia. Universitas Hasanuddin.

James P. Spradley. 2006. Metode Etnografi. Yogyakarta: Tiara Wacana, .

Edisi II Moleong, Lexy J. 2001. Metodologi Penelitian Kualitatif. Bandung: PT Remaja Rosdakarya.

Poplack, Shana. 1980. Sociolinguistics: An International handbook of the Science of Language and Society.

Rosnita, Dewi. 2013. Analisis Alih Kode dan Campur Kode Pada Novel Kuantar Ke Gerbang Karya Ramadhan K. H. E-Journal. Universitar Maritim Raja Ali Haji. Tanjung Pinang.

Santosa, Riyadi. 2014. Metode Penelitian Kualitatif Kebahasaan. Universitas Sebelas Maret.

Sumarsono. 2012. Sosiolinguistik. Yogyakarta: SABDA.

Sutopo. 2006. Metodologi Penelitian Kualitatif: Dasar Teori dan Terapannya dalam Penelitian. Surakarta: UNS Press.

Wardaugh, Ronald. 1992. An Introduction to Sociolinguistics. Oxford: Basil Black Well. 